studies of a more detailed character should precede research investigations. Suggesting that there might well be a place for a more heterodox training in mycology, he outlined a course for an honours degree in which, during the years subsequent to intermediate studies, chemistry, botany (exclupling the fungi) and mycology should be studied as parallel courses for two years and should be followed by a final year devoted entirely to mycology. The principles of bacteriology should be introduced during initial studies in mycology.

Mr. L. M. J. Kramer, speaking on "Mycology in Relation to Schools", said that it was mainly. during study for the higher school certificate or the university entrance examinations that the implications of mycology and the future openings for those able to undertake the necessary training could be presented to the scholars. Teachers would appreciate articles on simple laboratory exercises, on current trends in mycological studies and on openings for mycologists, as well as details of the necessary training, in such journals as the School Science Review.

In the discussion which followed the papers, Dr. Wilkins supported the separation of mycology from botany and hoped that the Society might influence university opinion to recognize mycology as a special subject for study. Dr. J. Ramsbottom considered that Mr. 'Kramer's suggestion that there was a lack of trained science teachers raised an important topic and stated that, while he would not enter the argu. ment for or against mycology being taught as a discipline separate from botany, it was essential to realize the great development of mycology during the past few years. Progress in teaching industrial mycology is slow at present but nothing can stop the development of this line of study. The hope for medical mycology lies in the fullest co-operation of the mycologist and practitioner. $\mathrm{He}_{\mathrm{e}}$ believed the possibility of a bulletin for amateurs sponsored by the Society might be considered. Mr. Large pointed out that plant pathologists had to be more than professional mycologists and that there was a decided lack of good drawings and simple descriptions of fungi. Dr. Wood was against any separation of botany and mycology and emphasized that plant pathologists had to be botanists. Dr. Cook believed that botany was outgrowing itself, that the difference between green plants and fungi was fundamental and that there was a place for a specialized mycology course following a general degree with botany as one of its subjects. Dr. Prentice deplored early specialization and considered that specialized graduate studies should follow a liberal first degree course. Dr. Keyworth thought a degree in botany was of fundamental value and that the necessity of a lengthened period of training by the introduction of postgraduate courses must be considered.

Reviewing the papers and the subsequent discus. sion, Prof. C. T. Ingold reminded members that the Society had developed from a field club to assume the lead in mycological thought in Great Britain without losing the essential characters of a field club. Its reports demonstrate its vital interest in adequate provision for mycological education and its encour. agement of taxonomic studies. Believing that the greatest weight should be placed on special postgraduate courses, Prof. Ingold referred to the present contribution of individual departments and suggested that industrial mycology might be established at technical colleges and, when medical education is reorganised, a place should be found for medical mycology. He considered that fungi should be treated outside the Thallophyta and that a reunion of bacteriology and mycology would be advantageous. Additional literature on the systematic side is urgently required. Prof. Ingold concluded by sug. gesting that the Committee of the Society which dealt with the teaching of mycology might continue its deliberations in the light of these discussions and might consider the institution of special series of lectures on mycological topics.

Charles G. C. Chesters

\section{A TRIBUTE OF INDUSTRY TO SCIENCE}

A SPECLAL meeting of the Industrial Research A Committee of the Federation of British Industries was held at the Royal Institution on March 19 in honour of Sir Robert Robinson and Sir Edward Appleton, who received the Nobel Prizes in 1947 for Chemistry and for Physics, respectively. Sir Frederick Bain, who presided, pointed out that not since 1904 had the prizes for chemistry and physics both come to Great Britain undivided and undisputed, although since 1901 Britain has had no less than thirty-six Nobel Prize awards in the five different categories. He described the meeting as a whole-hearted demonstration by British industry of pleasure at this authoritative recognition of the work of Robinson and Appleton, who now shared the distinction of Sir William Ramsay and Lord Rayleigh in 1904, and also a sincere recognition of what industry owes to science as represented by them. Sir Frederick said that he had been privileged to work intimately both with Sir Robert and Sir Edward, and that during the War we had learned how the scientist and industrialist could work together for a common objective. Great scientists could be effective men of affairs, and through the example and devotion of men like Robinson and Appleton, Britain had become, in war as in peace, not only a country of the questing mind and free experimental approach but also, above all, a place for sharing ideas, improvisation in emergency and effectiveness in application of scientific work.

Sir Robert Robinson, in a brief address on the "Scope of Organic Chemistry", referred to the way in which contact with industry has enriched our knowledge of organic chemistry, to the great stimulus which the study of complex molecules has given to organic chemistry and conversely to the contribution of organic chemistry to the development of the biological sciences. After referring to the opportunities for co-operation between different scientific workers afforded by such fields as catalysis and polymerization, and to the evolution in the last twenty years of the industry of aliphatic chemicals, Sir Robert stressed the national importance of organic chemical industry. In this connexion he urged the extension of facilities for research in organic chemistry and stressed the function of the universities in training research workers. For that function to be discharged effectively, parallel with the growth of industrial research laboratories and the expansion of technical colleges, there should be higher salaries for science teachers and the enlarging and modernization of university departments.

Sir Edward Appleton's address, "The Scientist in Industry", discussed in greater detail some aspects 
of the balance of the scientific effort of Britain now that it has recovered from the distortion due to our war effort. That effort, and particularly the development of the atom bomb, illustrated the rapidly increasing momentum of scientific and technical progress and the way in which the lag between scientific discovery and its practical application can be decreased. Sir Edward, emphasizing the importance of avoiding any segregation of our research effort whether in the universities, in Government departments, or in industry, said that while in the univ. ersity, where fundamental scientific research is mainly conducted, the only discipline is that of science itself, in Government and industrial research there is the further discipline of specified objectives, wide though these may be. The more liberally the restrictions imposed by the nature of the organisations which such scientific workers serve are interpreted, the better the scientific health of the men who work in them. Sir Edward then spoke of the broad lines of policy pursued by the Department of Scientific and Industrial Research, and of the necessity of a wise use of men of science in industry. He attributed our success in the War very largely to the mutual understanding which developed between the General Staff, the scientific workers and those responsible for production; and we need in peace the same sense of partnership between management, scientific men and other workers in industry. Commenting further on the importance of the human aspects of the scien. tist's work, he urged that the discipline of science should result in complete impartiality in interpreta. tion, and that the scientific worker should make his own contribution to the simplification of man. agerial decision, and particularly by clarity in expounding the results of his work. He described 'operational research' as meaning the application of scientific methods to the quantitative estimation of the effect of the changes in all kinds of factors which might influence industrial efficiency; and he said that, while industry before the War had often sought in this way to obtain reliable data as a basis for executive decisions, such methods could be of particular value at the present time in enabling science to contribute effectively to the increase of national productivity. The research associations are admirably fitted for such work.

The scientific worker in industry, Sir Edward said, has three principal functions : first, to provide a scientific service for his firm or industry ; secondly, to carry out research aimed at devising new or im. proved processes, goods and materials ; and thirdly, to contribute to the world's stock of scientific know. ledge. He believed that what scientific workers value most is the good opinion of their scientific colleagues, and it is impossible for them to feel they can acquire and retain this if their work is so circumscribed and limited in outlook as to cut them off entirely from the main stream of scientific progress. What matters most is not money and equipment, but men and leadership - above all, leadership which understands men.

Sir William Akers, in a tribute to Sir Robert Robinson, spoke of the extreme elegance of his methods as the distinguishing characteristic of his work on complex organic molecules ranging from the anthocyanins and alkaloids to the sterols, in which he had made organic chemistry a branch of physical chem. istry. His approach and methods in dealing with a problem were of intrinsic beauty, and this elegance was matched by his personal modesty. Sir William
Larke, in a tribute to Sir Edward Appleton, referred not only to his work on the exploration of the iono. sphere and his contribution to the development of radar, but also to his fine and human leadership of the Department of Industrial and Scientific Research. Sir William particularly welcomed Sir Edward's reference to the importance of exposition and interpretation, and to the view of operational research as a normal function of management. It was most fitting that the meeting should be held in the Royal Institution, where Faraday and others had carried out so much work upon which industrial development was based.

A complimentary dinner was given by the Federation to the two Nobel prize-winners that evening, and there were present the Prime Minister, the Lord President of the Council, the Minister of Food, the Minister of Fuel and Power, Lord Samuel, Lord Hankey, Lord Addison, Lord Cherwell and Sir John Anderson, the High Commissioners of New Zealand, India, Canada, Australia and Eire, and many other public men. The Prime Minister proposed a toast to the two guests of honour, saying that the recognition by the Federation of British Industries of the work of these two great men of science showed that the Federation appreciates the vital necessity for Britain to use to the full the resources of science if we are to hold our own in the mcdern world-and, he added, we are going to hold our own. He believed that industry is more alive than ever to the value of fundamental research, and he paid a tribute to the work of the Department of Scientific and Industrial Research. He hoped that the National Development Corporation would help to fill any gaps in the development of scientific discovery to full-scale production, and while the award of the Nobel Prizes to Sir Robert Robinson and Sir Edward Appleton showed that we are recognized as in the front rank in the field of science, he believed that Britain still has an immense contribution to make to the progress of the world.

Sir John Anderson, who seconded the toast, dealt more particularly with the scientific achievements of the two prize-winners, and stressed the importance of Sir Edward Appleton's work for radar during the War, and of Sir Robert Robinson's work for the supply of drugs and medicinals in the First World War. Sir Robert's rise to fame, in fact, coincided with the rise of the organic chemical industry in Britain, and Sir John remarked that while Britain has often led the world in fundamental science, we have not been quite so good in following up fundamental discovery.

Sir Robert Robinson, in responding to the toast, paid a warm tribute to the work of the many colleagues associated with him in his researches over the last forty years, among whom Lady Robinson had already been mentioned by the Prime Minister in a charming little tribute. Sir Edward Appleton, who also replied, said that in looking back over twenty-five years of research, he could not recall any sudden flashes of insight, although there had been many exciting moments. He reminded his audience that really great achievements are sometimes accidental and unin. tentional, and we should not be concerned exclusively with the material consequences of science. Science enlarges men's minds and could bring home to everyone the wonder and significance of the world in which we live. Science-teaching in our schools and universities should be far more than merely vocational training. In the intermational sphere, science means 
knowledge, and knowledge means power. Like other men, the scientific worker is deeply perturbed and morally concerned about the use or misuse of scientific knowledge. Atomic energy, for example, in itself threatens no one; but the possible use of atomic energy by nations prompted by hatred, envy or fear brings a new apprehension in our lives. The problems raised by this challenge are not for the scientific worker alone, though he has a right to his own views as a man of science; and Sir Edward stoutly supported a scheme of adequate international control at the present stage of the world's moral development, even while looking forward to a world in which such control would be unnecessary.

\section{OBITUARIES}

\section{Sir Charles Grant Robertson, C.V.O.}

Sir Charless Grant Robertson, who had been principal and, after the amendment of the University Charter in 1927, vice-chancellor of the University of Birmingham from 1920 until 1938, died at his home at Ringwood in Hampshire on February 29. Born in 1869, he passed from Highgate School to Hertford College, Oxford. There he had a brilliant career, being elected a fellow of All Souls in 1893. At Oxford he earned a reputation as a distinguished historian. In 1920 he was appointed principal of the University of Birmingham, to succeed Sir Oliver Lodge, the first principal, who had retired in 1919.

On the outbreak of war in 1914, the main buildings of the University of Birmingham at Edgbaston were immediately taken over by the War Office and converted into the First Southerm General Hospital, and what was left of staff and students was scattered to various crowded and inadequate quarters in the city. At the end of the War in 1918, the problem of recon. struction was immense. The buildings had to be cleared and restored to their proper functions and a battle had to be waged with the War Office for the cost of reconversion. Many temporary huts had to be erected to accommodate the flood of undergraduates surging in after demobilization, staffs had to be increased and money had to be raised. The University was heavily in debt and new and costly buildings were essential. An appeal for half a million pounds was therefore launched. The new principal used his remarkable powers of eloquent persuasion, both in public and in private, to great effect, and soon large sums came in from generous Birmingham. benefactors, and some of the much-desired ideals became realities. The new Biological Block was built; to the department of chemistry was added the Hills Chemistry Block; and through the muni. ficence of Sir Charles Hyde the Hall of Residence (Chancellor's Hall) and the Students' Union came into being. Sir Charles Grant Robertson used his organising abilities to get a better balance between the faculties by the development of the Arts side and extending the Library. A faculty of law was established, with a chair endowed by Mr. Henry Barber.

Another project dear to the heart of the principal was the building and endowment by Lady Barber, in memory of her husband, of the Barber Institute of Fine Arts. This Institute, which has a beautiful music room in addition to its picture galleries, pro. vides the students with rare opportunities for cultural education outside the routine courses. Behind all this development was always the energetic personality of Sir Charles.

But perhaps the greatest and most far-reaching of Sir Charles' activities was his advocacy of the Hospitals Centre, with an associated medical school. For thirteen years he laboured unceasingly as chairman of the Hospitals Centre Committee with a generous, energetic and resourceful band of fellow citizens, and finally had the satisfaction of seeing the completion (or, perhaps more exactly, 'the end of the beginning') of their work in the form of the great Queen Elizabeth Hospital, in front of which extends the magnificent building of the Medical School, a visible monument to the solidarity of the University and the City. The persistent energy with which Sir Charles Grant Robertson worked for the advancement of the University of Birmingham in all its branches has left an abiding mark on the great city of whose long line of great 'peaceful invaders' he was not the least. G. A. Shakespear

\section{Mr. Griffith Brewer}

By the death of Mr. Griffith Brewer on March 1, the fraternity of aeronautical pioneers has lost a well-beloved and much respected friend. Brewer was born in London in 1867 and was by profession a patent agent. For nearly sixty years his chief interest lay in aeronautics, and he was not only an authority on aircraft patents but also a notable balloonist and, later, an aviator who bore the distinction of being the first Englishman to fly in an aeroplane-as a passenger with Wilbur Wright in 1908. Abroad, he was perhaps best known for his work and friendship with Wilbur and Orville Wright and, in particular, for the part he played in the so-ealled 'Wright Langley controversy'.

Griffith Brewer was a man of marked integrity and courage; he displayed these virtues to the full when investigating and exposing the claims made in respect of Prof. Langley's 'aerodrome' after its reconstruction and flight in 1914-claims which he regarded as damaging to the credit of the Wright brothers. He was instrumental in 1928 in obtaining the original Wright aeroplane of 1903 for exhibition in the Science Museum, London, as a further step towards securing unqualified recognition of the Wrights' achievement. This recognition is now happily established and shortly to be confirmed by the return of the machine to the United States for preservation in the National Museum at Washington. His vindication of historical truth in that issue is likely itself to pass into history. In 1913, Brewer was entrusted with the formation of the British Wright Company to administer the Wright brothers' patents in England.

Brewer obtained his pilot's licence at Dayton, Ohio ; in 1933 he gained a licence for flying autogiros. He served for many years on the Council of the Royal Aeronautical Society, of which he was a pastpresident; and in 1912 founded the Society's Wilbur Wright Memorial Lecture. His gentle presence and kindly nature will be missed there. M. J. B. DAvY

WE regret to announce the following deaths :

Prof. A. S. Eve, C.B.E., F.R.S., emeritus Macdonald professor of physics in McGill University, on March 24, aged eighty-five.

Prof. M. C. Potter, emeritus professor of botany in the University of Durham since 1925, on March 9, aged eighty-nine. 